\title{
Caledonian deformation of the Precambrian basement in southeastern Norway
}

\author{
Arne Bjørlykke' \& Odleiv Olesen ${ }^{1}$ \\ ${ }^{1}$ Geological Survey of Norway, Post Box 6315 Torgarden, 7491 Trondheim, Norway. \\ E-mail corresponding author (Arne Bjørlykke): arne.bjorlykke@ngu.no
}

\begin{abstract}
The Precambrian basement in southeastern Norway consists of the Transscandinavian Igneous Belt (TIB) with ages from 1.86 to 1.66 Ga to the east of the Mjøsa Mylonite Zone. Gothian rocks with an age of 1.64-1.52 Ga occur to the west of this zone together with the highly magnetic 932 Ma old Flå Granite. A map showing the depth to the Precambrian basement in southeastern Norway is based on depth to magnetic basement, gravity models and the position and height of the Cambrian marine transgression in southeastern Norway. The peneplain has a slope facing northnortheast on the western side of Mjøsa and west of the Mjøsa Mylonite Zone. On the eastern side of Mjøsa the slope is facing northwestwards. This basin structure may be primary or partly a result of later subsidence. We propose that the basement depression extending from Lillehammer to the north-northwest represents the southern extremity of a basement structure that hosted the Hedmark Basin. The broad basin can be followed to the north by magnetotelluric surveys to Dovrefjell were it terminates at the late, large, normal fault at the boundary to the Upper Allochthon. Within the zone of deformed basement west of the Mjøsa Mylonite Zone, there are three 3-4 km-deep basins/depressions. The depressions are probably produced by Caledonian thrusting of the basement and are related to the transport of the Atnsjø window and the Osen-Røa Nappe Complex. New data from Åreskutan in Sweden on the thrusting of the Middle Allochthon during Late Silurian and the thrusting of the Lower Allochthon in Early Devonian are in agreement with data from Trollheimen in Norway. The Early Devonian Osen-Røa Nappe is probably related to the out-of-sequence Storli Thrust, and the thrusting involved the sedimentary cover including the Hedmark Basin and the basement below. The distance of transport may have been in the order of $100 \mathrm{~km}$.
\end{abstract}

Keywords: Caledonian Orogen, Norway, sparagmite, Edicarian, Cambrian, depth to basement, magnetometry, gravimetry,

Received 24. May 2018 / Accepted 10. November 2018 / Published online 18. January 2019

\section{Introduction}

The distance of thrusting of the Middle and Lower allochthons in the central part of the Caledonian Orogen has been discussed since the time of Törnebohm's famous 1888 paper and his map from the central part of Scandinavia (Törnebohm, 1896). Törnebohm (1888) based his tectonic model on the same profile crossing Åreskutan as in Gee et al. (2010) more than 120 years later and estimated the transport distance for the Middle Allochthon to be in the order of $100 \mathrm{~km}$. On his map, Törnebohm (1896) separated with hatching the longtransported nappes of the Middle Allochthon from the shorter-transported nappes of the Lower Allochthon.
Different estimates for the transport distance of the thrusting of the Lower Allochthon based on shortening of the Osen-Røa Nappe Complex have been published by Morley (1986) and Lamminen et al. (2011) and references therein. Morley (1986) calculated the shortening to be in the order of $150 \mathrm{~km}$. Rice \& Anderson (2016) interpreted transport distances of 280 and $70 \mathrm{~km}$, respectively, for the Hedmark Basin and the Western Gneiss Region in Mid Norway. In the models involving a long transport of the Lower Allochthon, the Hedmark Basin is located north of the Precambrian basement windows (Nystuen, 1981; Lamminen et al., 2011).

Skjeseth (1963), Englund (1973), Bjørlykke (1983) and Bjørlykke et al. (1976), argued for a short transport

Bjørlykke, A. \& Olesen, O. 2018: Caledonian deformation of the Precambrian basement in southeastern Norway. Norwegian Journal of Geology 98 , 1-16. https://dx.doi.org/10.17850/njg98-4-05. 
distance of the Osen-Røa Nappe Complex based on the relationship between the marginal deposits in the Hedmark Basin and the basement structures. Nielsen \& Skovsbo (2010) estimated the travel distance to be in the order of $100 \mathrm{~km}$ based on the palaeogeographic reconstruction of different periods during the Early Cambrian. Worsley et al. (2011) indicated the same distance on their palaeobathymetric maps from the Silurian Bruflat Formation. There are, however, large uncertainties in the estimates and we still don't know the exact transport distance of the Osen-Røa Nappe Complex (Bruton et al., 2010; Fossen et al., 2013).

There has been an increased awareness of Caledonian deformation and thrusting of the Precambrian basement (Fossen et al., 2013) in the Caledonian Orogen in Scandinavia. Seismic surveys show Caledonian structures deep into the Precambrian basement and large slices of basement occur within Caledonian nappes. Fossen et al. (2013) show on page 192 an early thrusting of the basement in the Ordovician along the northwestern margin of the Fennoscandian Shield that ends with the continent-continent collision in the Late Silurian to Devonian, and a significant part of the Precambrian basement had by then been Caledonised. How far to the southeast can we see the effects of Caledonian deformation beneath the Lower Allochthon in southeastern Norway? And may some of the compressional structures in the basement represent reactivation of earlier extensional rift structures similar to the situation in northern Central Norway described by Braathen et al. (2002)? The deformation of the Precambrian basement is also important in the estimation of the transport distance of the basement slices occurring within the Caledonian nappes and in quantifying the shortening of the basement.

Hurich et al. (1988) recognised deep reflectors beneath the Skardøra tectonic window (near Storlien) at a depth of $20 \mathrm{~km}$ and interpreted them to be Caledonian thrusts. Gee et al. (2016) proposed the concept of an underlying autochthonous basement separated by a thrust zone from an overlying allochthonous basement with metamorphic sediments and volcanites as shown in the schematic profile from Østersund to Trondheim (Figs. 1 \& 2). The geological profile is partly based on seismic reflection profiling. The location of this profile is depicted in Figs. 3-6. Gee et al. (2010) showed a reflection seismic profile from Østersund to the Norwegian border, and interpreted the reflectors, dipping gently to the west, to represent major thrusts within the Precambrian basement. The compression and shortening of the upper crust above the reflectors indicate thrust movements in the order of several tens of kilometres. This interpretation is supported by a magnetotelluric survey along the same profile (Korja et al., 2008). This geophysical profile ends, however, at the Norwegian-Swedish border.

In 1976, Knut Åm made the first map of the depth to magnetic basement of the area, and the results were published in a paper by Nystuen (1981). He found three 3-4 km-deep depressions, and they were interpreted by Nystuen (1981) to have been caused by late Caledonian (Devonian?) subsidence. There are, however, few signs of such large-scale subsidence in the surface geology in the areas above the depressions.

The second important part of the present paper concerns the structural position of Precambrian windows (Atnsjø, Spekedalen, Øversjødalen Tufsingdalen and Steinfjellet) and of slices of Precambrian basement in the OsenRøa Nappe Complex in relation to the Caledonian deformation of the Precambrian basement, which is expressed on the magnetic and gravity maps. The allochthonous position of the Precambrian windows within the Osen-Røa Nappe Complex (Lamminen et al., 2014) makes it interesting to compare the tectonostratigraphy in the Trollheimen/Western Gneiss Region with the tectonostratigraphy southeast of the Precambrian windows. Robinson et al. (2014) relate the thrusting of the Precambrian window at Mullfjället (located to the west of the COSC borehole in Figs. 4-7) to a late, out-of-sequence thrusting at around $395 \mathrm{Ma}$ and interpreted the window to be tectonically a part of the Lower Allochthon. The thrust below the Precambrian window is probably a continuation of the Storli Thrust in Trollheimen (Robinson et al., 2014).

In this paper we look at the relationship between the thrusting of the Middle Allochthon and the Lower Allochthon with the basement windows. The involvement of the basement on the Fennoscandian Shield was probably important for the transport of the Hedmark Basin out of its several km-deep rift structure into an overturned antiform during the thrusting of the Osen-Røa Nappe Complex.

\section{Geological setting}

The geology of the southeastern Norway is composed of a Mesoproterozoic basement with autochthonous Cambrian metasedimentary rocks above. This sequence is cut by Caledonian nappes (Lower, Middle, Upper and Uppermost allochthons (Gee et al., 2010; Figs. 1 \& 2)). The Lower Allochthon is composed of sedimentary rocks and basement slices from the interior of the Fennoscandian Shield, whilst the Middle Allochthon consists of rocks from the northwestern Fennoscandian margin. In the Upper Allochthon there are mainly rocks from island arc and spreading ridge environments and the Uppermost Allochthon represents rocks from the Laurentian side of the Iapetus Ocean.

The Mezoproterozoic basement in southeastern Norway (Fig. 3) is composed of the Transscandinavian Igneous Belt (TIB) with an age of $1.86-1.66 \mathrm{Ga}$ to the east. It is 
A)



C)



B)

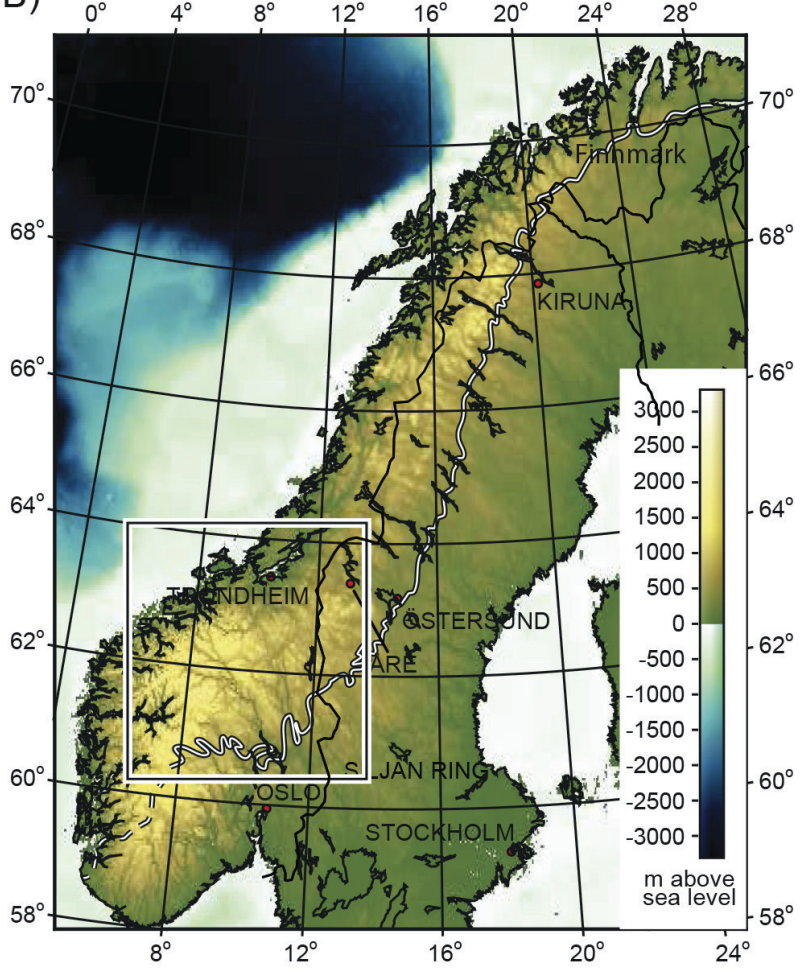

D)

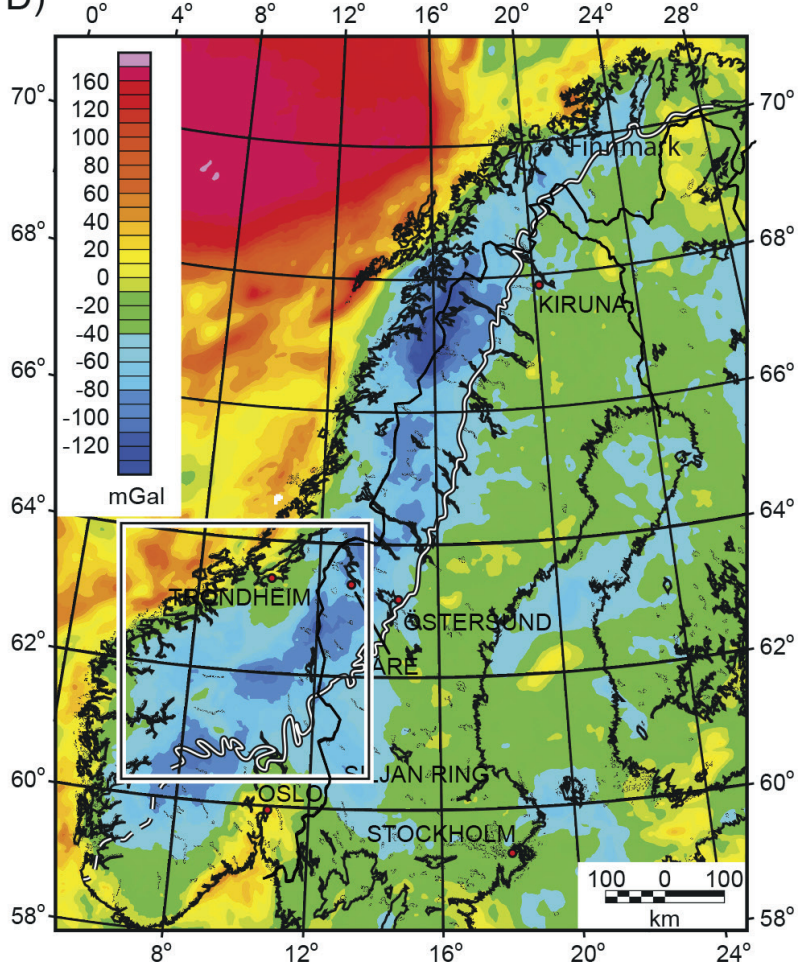

Figure 1. (a) Tectonostratigraphic map of the Scandinavian Caledonides (based on Gee et al., 2010). (b) Topography/bathymetry of northwestern Scandinavia (prepared with GMT). (c) Magnetic anomaly map (based on Olesen et al., 2010). (d) Bouguer gravity anomaly map (based on Olesen et al., 2010). Black rectangle shows the extent of the geophysical and geological maps in Figs. 4-7, the dashed red and white line is the national border and the black and white line is the Caledonian front. The figure is modified from Hedin et al. (2014). 


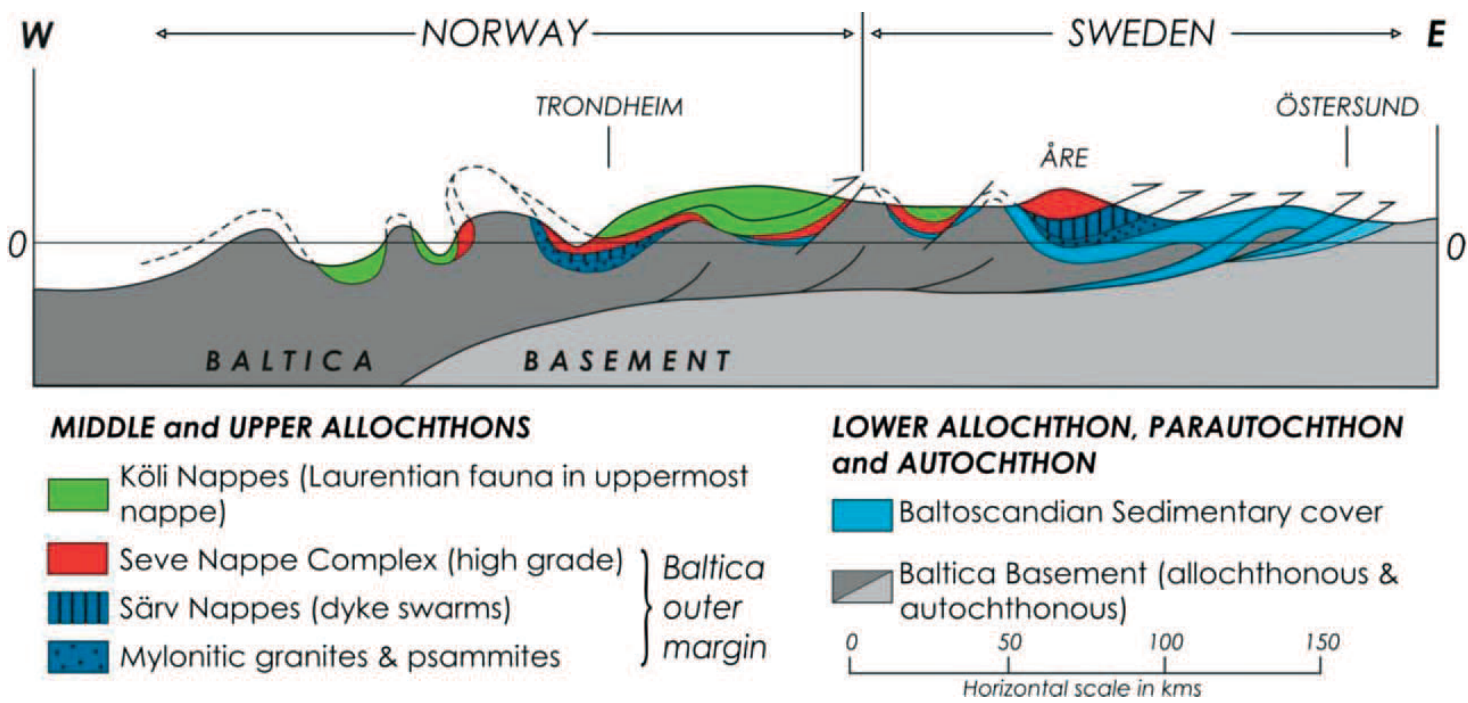

Figure 2. Schematic profile through the Central Scandinavian Caledonides (Gee et al., 2010). The location of the profile is shown in Figs. 1 \& 4-7.



1: Sveconorwegian Front

2: Eclogite-bearing nappe

3: Mylonite Zone

4: Göta-Älv Shear Zone

Ørje Shear Zone (Norway)

5: Østfold-Marstrand Boundary Zone

6: Kristiansand-Porsgrunn Shear Zone

7: Saggrenda-Sokna Shear Zone

8: Mandal-Ustaoset Fault \& Shear Zone

9: Approximate northern boundary of

Sveconorwegian overprint in the

Western Gneiss Region

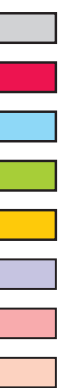

Caledonian + Phanerozoic
Eastern Segment
Idefjorden Lithotectonic Unit
Bamble \& Kongsberg Lithotectonic Units
Telemarkia Lithotectonic Unit
Western Gneiss Region
Transscandinavian Igneous Belt
Svecokarelian orogen

Figure 3. The Precambrian basement of the southern part of Scandinavia (after Bingen \& Viola, 2018).

followed to the west by the 1.64-1.52 Ga old Eastern Segment and the Idefjorden Lithotectonic unit and the 1.52-1.48 Telemarkia Lithotectonic Unit (Bingen \& Viola, 2018). On the border between the TIB and the Idefjorden unit there is a major Sveconorwegian mylonite zone (Mjøsa). The Sveconorwegian frontal deformation zone is situated to the east of the Mjøsa Mylonite Zone (Fig. 3). Between these two zones there is a marked Sveconorwegian deformation of the Precambrian basement.
The NNW-SSE lineaments are prominent in the basement areas and they also dominated the tectonic evolution with rifting in the Neoprotereozoic-Early Cambrian and during the Permian period (Lamminen et al., 2014).

Due to erosion and chemical weathering during the Ediacaran period, the Precambrian basement became a peneplain at the start of the Early Cambrian, In some areas northwest of the Caledonian front, the Moelv Tillite 
is found directly on the basement. To the southwest, the Middle Cambrian Alum Shale Formation is deposited directly onto the basement.

The Lower Allochthon consists in the southeastern area of Lower Cambrian sedimentary rocks thrusted above the Middle Cambrian Alum Shale Formation (Sole Thrust, Gabrielsen et al., 2015). Towards the central part of the Caledonian Orogen, Ediacaran metasedimentary rocks and basement slices, as well as the basement windows', are included into the Lower Allochthon. The slices of basement rocks in the Lower Allochthon show that the sole thrust of the Lower Allochthon must be located within the Precambrian basement (Gee et al., 2010; Robinson et al., 2014).

There is a clear difference between the Middle and the Lower Allochthon. The Middle Allochthon consists of sedimentary rocks that were deposited along the margin of the Fennoscandian Shield, the Särv Group with dolerite dykes related to the opening of the Iapetus Ocean (Gee, 1975), UHP rocks of the Seve Nappe Complex and Precambrian augen gneisses.

Ladenberger et al. (2014) have studied the Seve Nappe Complex and concluded that the Seve UHP eclogites formed at $441 \mathrm{Ma}$ during an initial collision of Baltica with Laurentia. The exhumation of the Seve Nappe Complex resulted in the formation of Silurian foreland basins and the authors also suggested that the thrusting of the Seve Nappe Complex took place at $420 \mathrm{Ma}$.

At the southeastern front of the Caledonides, autochthonous Cambrian sediments were deposited on the Precambrian basement, which was undeformed during the subsequent Caledonian Orogeny. The old Early Cambrian peneplain shows only gentle undulations. One exception occurs in the area on the northeastern side of Lake Storsjøen where the Ediacaran tillite is deposited on the Trysil granite. A similar sequence also occurs close by in the Lower Allochthon due to an out-of-sequence thrusting (Sæther \& Nystuen, 1981).

The paleosurface of the Precambrian basement is important for the understanding of Caledonian and Permian faulting and deformation. The peneplain is well exposed along the Caledonian front. In particular, on the western side of lake Mjøsa it is cropping out on the slopes of the valleys. Hardangervidda is a culmination with a slope to the northwest along the western part of Hardangervidda and a slope facing northeast in the area between Hardangervidda and Mjøsa (Bjørlykke, 1979; Gabrielsen et al., 2015). On the eastern side of Mjøsa the slope is again facing northwest. Caledonian deformation of the peneplain is difficult to identify.

\section{Geophysical data}

\section{Aeromagnetic data}

The whole of Norway was covered with aeromagnetic surveys from 1959 to 1975 (Fig. 4). Flight altitudes, flying directions, and line spacing of the aeromagnetic surveys varied widely (Olesen et al., 2010). The line spacing and flying altitude of the Trøndelag and eastern Norway regions were $500 \mathrm{~m}$ and $150 \mathrm{~m}$, respectively. The Rondane region was flown with a spacing of $2.5 \mathrm{~km}$ and constant altitude of c. $1500 \mathrm{~m}$ above sea level and is consequently a quite coarse dataset with low resolution. The coastal region of western and central Norway was surveyed within the Coop project (Crustal Onshore-Offshore Project) with a line spacing of $250 \mathrm{~m}$ and a drape altitude of 60 m (Novatem, 2012, 2014; Nasuti et al., 2015; Olesen et al., 2015). The fjord and mountain region of western Norway was drape-flown with an altitude of 200-700 $\mathrm{m}$ and a line spacing of $1 \mathrm{~km}$ (Eon, 2014; Nasuti et al., 2015; Olesen et al., 2015). Parts of central Norway have, in addition, been covered with helicopter-borne magnetic data for mineral exploration (Nasuti et al., 2015; Rodionov et al., 2015). The IGRF field was calculated and subtracted from the levelled survey lines to produce the magnetic anomalies of the survey areas. Aeromagnetic data collected on the Norwegian mainland prior to 1976 and aeromagnetic data from Sweden (Korhonen et al., 2002a) have been merged with the more modern fixed-wing and helicopter-borne surveys (Nasuti et al., 2015; Olesen et al., 2015). The cell size of the final grid is $100 \times 100 \mathrm{~m}$.

\section{Gravity data}

The gravity compilation has been described by Skilbrei et al. (2000) and Olesen et al. (2010) (Fig. 5). The compiled dataset was merged with gravity data in Sweden (from the $2.5 \times 2.5 \mathrm{~km}$ Fennoscandian grid; Korhonen et al., 2002b). The compiled free-air dataset has been interpolated to a square grid of $2 \times 2 \mathrm{~km}$ using the minimum curvature method (Briggs, 1974; Geosoft, 2005). The Airy-Heiskanen 'root' (Heiskanen \& Moritz, 1967) was calculated from a smoothed version of the compiled topographic and bathymetric dataset (Fig. 1b). The gravitational attraction from the 'root' was calculated using the AIRYROOT algorithm (Simpson et al., 1983). The isostatic residual was achieved by subtracting the gravity response of the Airy-Heiskanen 'root' from the observed Bouguer gravity data. The Airy isostatic residual map (Fig. 5) provides an improved image of crustal structures compared with traditional free-air and Bouguer gravity maps.

\section{Depth to Precambrian basement}

We have constructed a map showing the depth to the Precambrian basement in southern Norway (Fig. 6). The 
$8^{\circ}$

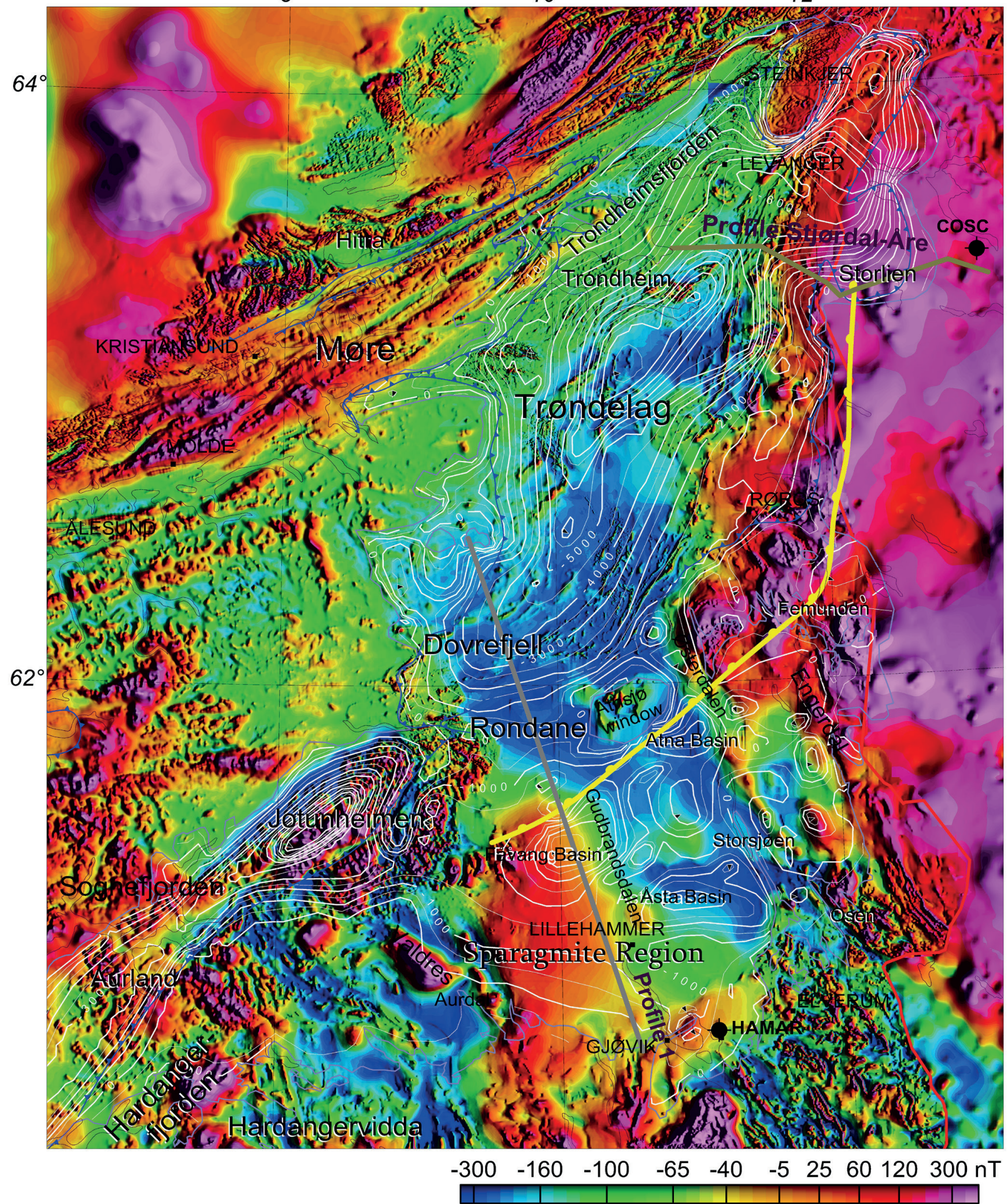

Figure 4. Aeromagnetic compilation from central and southeastern Norway. The estimated depth to the Precambrian basement is shown with white contours. Late-Caledonian detachments (Séranne, 1992; Braathen et al., 2002; Osmundsen et al., 2006; Robinson et al., 2014) are shown as blue lines with the barbs towards the downthrown side. The grey line depicts the location of the interpretation profile shown in Figs. $8 \& 9$. The yellow line indicates the interpreted southeastern boundary of Caledonian deformation of the Precambrian basement. The black circles show the locations of the Hamar and COSC boreholes. 
$8^{\circ}$ $10^{\circ}$ $12^{\circ}$



Figure 5. Gravimetric isostatic residual map of central Norway and adjacent areas (Olesen et al., 2010). The estimated depth to Precambrian basement is shown with black contours. Late-Caledonian detachments are shown as blue lines with the barbs towards the downthrown side. Profile 1 depicts the location of the interpretation profile shown in Figs. $8 \mathrm{\&}$ 9. The yellow line indicates the interpreted southeastern boundary of Caledonian reworking deformation of the Precambrian basement. The black circles show the locations of the Hamar and COSC boreholes. 


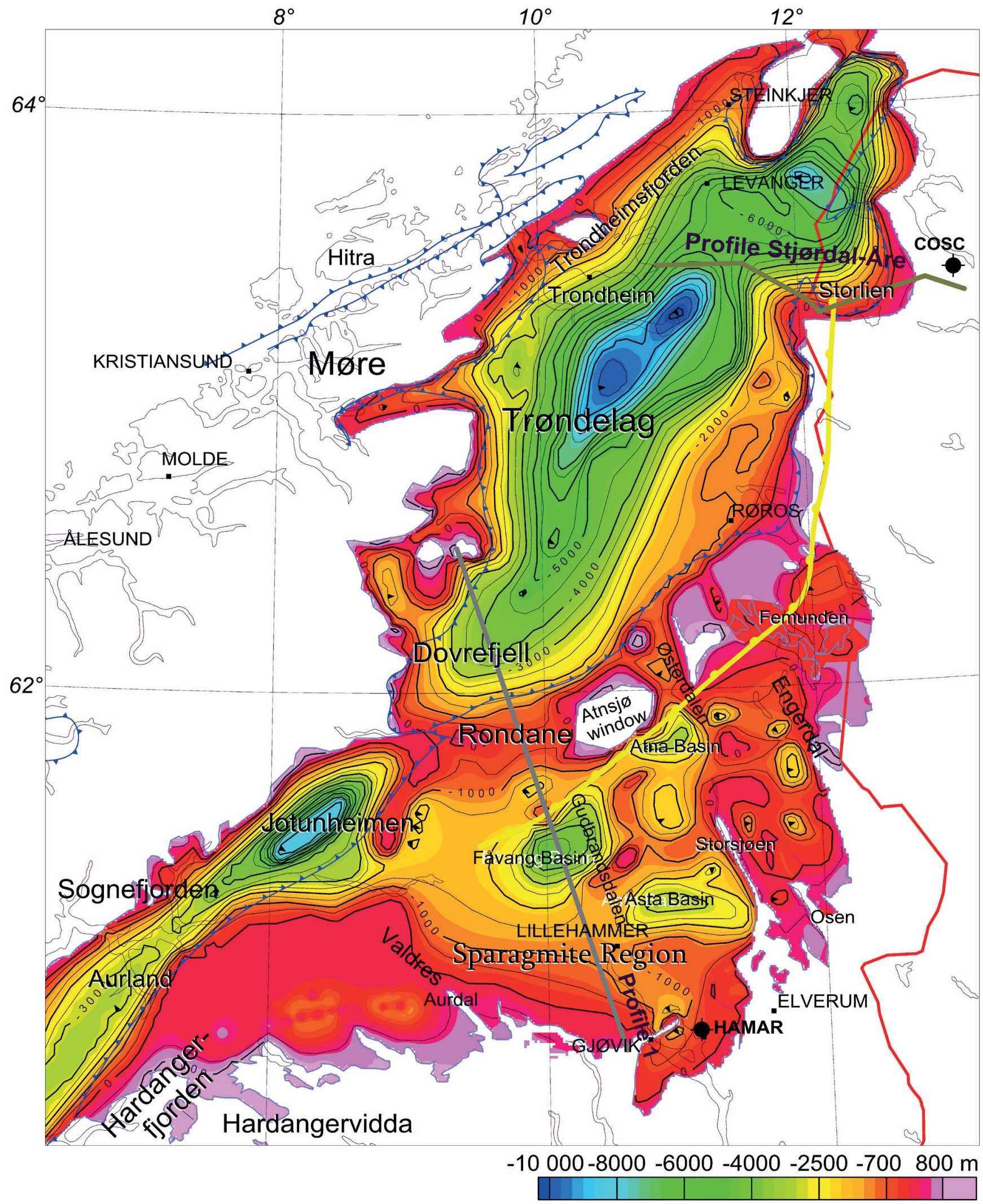

Figure 6. Depth to Precambrian basement in central and southeastern Norway based primarily on magnetic depth estimates by Knut Åm (in Nystuen, 1981) and gravity models in Trøndelag, Jotunheimen and Vestlandet (Skilbrei \& Sindre, 1991; Skilbrei et al., 2002; Mekonnen, 2004; Olesen et al., 2007a, b). Late-Caledonian detachments (Séranne, 1992; Braathen et al., 2002; Osmundsen et al., 2006; Robinson et al., 2014) are shown as blue lines with the barbs towards the downthrown side. Profile 1 depicts the location of the interpretation profile shown in Figs. 8 \& 9. The yellow line indicates the interpreted southeastern boundary of Caledonian deformation of the Precambrian basement. The black circles show the locations of the Hamar and COSC boreholes. 
depth map (the surface of the Precambrian basement), is generalised and simplified. In the Sparagmite Region the metasedimentary rocks are practically non-magnetic, whereas some of the rock units inside the Jotun Nappe Complex and the Trondheim Nappe Complex are highly magnetic and relatively dense. Within the Sparagmite Region, the map is a reproduction of the published contour map of depth to magnetic basement (by Knut Åm in Nystuen, 1981). It is considered to reflect undulations of the crystalline basement-cover interface. The applied straight slope method assumes that the basement has a varied magnetisation that seems to be the case for the Precambrian crust in southern Norway (Fig. 4). Over large areas, this surface is the so-called 'sub-Cambrian peneplain' (Nystuen, 1981), on which the erosionally truncated magnetic bodies occur (some bodies may also occur beneath this surface). The south and central Norwegian Caledonides include the Trondheim Nappe Complex, Jotun Nappe Complex and Caledonian rocks in the greater Hardangerfjorden area. In the area encompassing Trøndelag, Dovrefjell and Jotunheimen, the depths are based on gravity models. In a transect from Trondheim to Storlien, the gravity models were constructed by Wolff (1984), Skilbrei \& Sindre (1991), Skilbrei \& Kihle (1998) and Skilbrei et al. (2002). Elsewhere in Trøndelag a model was constructed by Mekonnen (2004). An estimate of the uncertainty is that the maximum depth of the Caledonian nappes is in the interval $8 \mathrm{~km}$ to $12 \mathrm{~km}$ in the Trondheim Nappe Complex. Beneath the Jotun Nappe Complex, it is 6-10 km (Skilbrei, 1990). South and southwest of Jotunheimen, the depths are based on the dips of units measured on geological sections that appear in geological maps at a scale of 1:250,000 published by Lutro \& Tveten (1996), Nordgulen (1999), Siedlecka et al. (1987) and Sigmond (1998). The depicted basement surface is smoothed and simplified and is considered to represent the base of the supracrustal units of CambroSilurian age, or the bottom of the Caledonian allochthon. This basement depth surface was also discussed by Ebbing et al. (2012). In the present contribution we have extended the surface to the autochthonous sedimentary rocks below the Caledonian front (Koistinen et al., 2001) by including the height of this structure in the gridding process. The previous versions were truncated at the depth of sea level. The depth surface has a more pronounced relief in the Sparagmite Region than in the other areas. This is partly due to the higher resolution of the depth to magnetic basement estimates. Relatively flat-lying magnetically transparent nappes are situated on top of the magnetic basement.

A borehole near Hamar confirms the depth to basement calculated by Åm in Nystuen (1981) and the basement contact was intersected at a depth of $770 \mathrm{~m}$ (Midttømme et al., 2007; Olesen et al., 2007a; Elvebakk \& Lutro, 2008). The depression at Hamar is in good agreement with the depth to basement map showing a depression towards the north-northwest. This depression is situated near the Mjøsa Mylonite Zone in the Precambrian basement (depicted as Mylonite Zone in Fig. 3).

\section{Linking geology and geophysics}

The new magnetic and gravimetric maps of Southeast Norway with superimposed depths to basement are shown in Figs. 4 \& 5. The basement depressions mapped by Knut Åm in the Sparagmite Region (Nystuen, 1981) occur in the Eastern Segment (Fig. 3) to the east of the Mjøsa Mylonite Zone, and west of the relatively undeformed TIB rocks (Gaal \& Gorbatschev, 1987; Henkel \& Eriksson, 1987). These rocks are c. $1700 \mathrm{Ma}$ old rhyolites, granitic intrusions and gabbros (Larson \& Berglund, 1992). The three basement depressions are unique along the Caledonian front in southern Norway with a depth to basement of 3 to $4 \mathrm{~km}$. We have named the depressions the Atna, Fåvang and Åsta basins from north to south (Figs. 4-6). The slopes of the basin margins are rather steep with gradients in the order of $1: 10$ and $1: 5$.

The basement windows can be followed on the aeromagnetic map from the Skardøra Antiform near Storlien on the Stjørdal-Åre profile (Hurich et al., 1988, 1989; Palm et al., 1991; Hurich, 1996; Hurich \& Roberts, 1997; Juhojuntti et al., 2001; Gee et al., 2010; Hedin et al., 2012), towards the Atnsjø window in the southwest (Fig. 4). The magnetic signature reflects the deformation in the allochthonous basement (Gee et al., 2010). As pointed out by Nystuen (1981), the highs are continuous with the basement windows in the northern part of the Sparagmite Region (Fossen et al., 2013). The windows that form the axial culminations of an antiformal ridge extend from Aurland and Valdres in the southwest to the Storlien area at the NorwegianSwedish border in the northeast. The basement depths can represent culminations and depressions arranged en echelon and parallel to the antiformal ridge along the southeast margin of the Trondheim Nappe Complex, and a common origin for the basement undulations is likely (Nystuen, 1981). In fact, the observation that "the sedimentological boundaries, thrust planes and basement domes bend parallel in the windows and the basement flexures in the Sparagmite Region, suggest late- and/or post-Caledonian age for these structures" (Nystuen, 1981). In the Femunden area near the Swedish border, the TIB basement is deformed and the main lineation trend changes from NNW-SSE to NE-SW (Fig. 3). As described in several publications (e.g., Gee, 1975; Dyrelius, 1980; Hurich et al., 1988, 1989; Roberts \& Stephens, 2000; Gee et al., 2010; Robinson et al., 2014), the basement will gradually become more and more involved in the Caledonian deformation to the northwest. The major thrust under the Atnsjø Window is probably the continuation of the out-of- sequence Storli Thrust in Trollheimen.

The depth to basement map shows depths in the order of 8 to $12 \mathrm{~km}$ in central Trøndelag, which indicate the presence of the Storli Thrust below the Middle and Upper 
allochthons (Robinson et al., 2014, p. 262, Fig. 13). Also Gee et al. (2010) show an early thrusting of the Middle Allochthon before the thrusting of the allochthonous basement. Slices of Precambrian basement can also be found in the Osen-Røa Nappe Complex on the eastern side of Lake Storsjøen at Andrå (Sæther, 1979). The Moelv Tillite is here deposited directly on autochthonous Precambrian granite, and a few hundred metres to the north slices of granitic basement with overlying Moelv Tillite are thrust onto the autochthonous successions which indicate a very short distance of transport. Sæther (1979) related the thrusting of the basement to a late D4 deformation (Sæther \& Nystuen, 1981). The out-ofsequence thrusting in the Osen-Røa area was proposed as one of two models by Nystuen (1983) and has also been described by Lamminen et al. (2011).

The strong Caledonian lineation in the basement in the Femund-Storsiøen area can be extended to the west. We will call this line the southeastern magnetic limit of the Caledonian deformation of the basement (yellow line in Figs. 4-6 and green line in Fig. 7). The Atna depression/ basin is situated south of the Atnsjø window and the slope of the basement surface is very steep and may indicate a thrusting of the basement onto the parautochthonous sediments. The Fåvang basin also has a similar steep slope to the northwest that may reflect a continuation of the basement culmination to the southwest.

The thrust zone separating the allochthonous basement from the autochthonous basement is probably located in the lower part of these two basins. The location and the shape of the Åsta basin are somewhat different. It may be a combination of a primary basin with Ordovician/ Silurian subsidence and a Caledonian out-of-sequence thrusting.

Due to the presence of the magnetic Jotun Nappe Complex west of Miøsa and Gudbrandsdalen, the magnetic structures in the basement are more difficult to interpret in this area. On the 1:100,000 bedrock map-sheet Aurdal, Strand (1954) found two slices of Precambrian rocks in the Osen-Røa Nappe Complex. At Haugen $5 \mathrm{~km}$ west of Aurdal (Fig. 4), a slice of Precambrian basement with overlying Lower Cambrian sedimentary rocks has been thrust above a thin unit of autochthonous sediments. Strand (1954) concluded that the slice originated from the local basement and that the peneplain had been deformed.

The Vangsås Formation was not intersected by the drillhole north of Hamar (Fig. 4), and the drillhole therefore marks the southern limit of thrusting of the Vangsås Formation in the Osen-Røa Nappe Complex in the Mjøsa region. The distance from the borehole at the northern limit of the autochthonous Vangsås Formation to the limit of the Caledonian deformation of the basement (the green line in Fig. 6) is approximately
$100 \mathrm{~km}$. This is the same setting as described above from Andrå at the northern part of Storsjøen (Fig. 4).

Post-Caledonian faults also affect the structures, including faults related to the Oslo Rift, and many fault zones may represent reactivated Precambrian fault-I weakness zones. Most faults are parallel to the NNWSSE-trending Mjøsa Mylonite Zone, and lineaments in the magnetic map can be seen along the Engerdal, Rendalen and Osen fault zones (Nystuen, 1975a, b, 1976a, b, c, 2008; Nystuen et al., 2008; Gabrielsen et al., 2017) indicating that they have activated the underlying Precambrian fault structures. The basement structures are influencing the basement topography and sedimentary facies in the Lower Cambrian. Galena mineralisations in the autochthon of Early Cambrian age occur close to the fault zones and also indicate tectonic movements at that time. Veins in the basement with sphalerite and galena mineralisations at Storuman in Sweden have been dated by Billström et al. (2012) to $536 \pm 13 \mathrm{Ma}$. The Engerdal, Rendalen and Osen fault zones have also been active during the Permian and by interpreting the depth to basement map, vertical movements in the order of 500 metres can be estimated (Fig. 6).

\section{Discussion}

\section{Deformation of the autochthonous Precambrian basement}

Based on a compilation of detailed stratigraphic work in the Lower Cambrian, Nielsen \& Skovsbo (2010) constructed several palaeogeographic maps of the Fennoscandian Shield. The Early Cambrian sea formed a bay in the Mjøsa area during transgressive periods. On the western side of Miøsa, the slope of the Precambrian basement was about 2-3 degrees to the northeast, whereas the basement had a northwesterly slope on the eastern side of Mjøsa. This is probably reflecting the primary palaeosurface on the Fennoscandian Shield.

The three basins or depressions interpreted by Knut Åm (Nystuen, 1981) between the Mjøsa Mylonite Zone and Rendalen occupy small areas. They are, however, relatively deep (3-4 $\mathrm{km})$ and are unique along the Caledonian front in southern Norway. Because of their small size (500 to $1000 \mathrm{~km}^{2}$ ) they cannot have hosted the sediments of the Hedmark Group. The steepest slopes are on the northern sides of the basins. The depressions have been explained by late-Caledonian subsidence (Devonian collapse?) by Nystuen (1981). Such a subsidence, however, is not reflected in the surface geology (Fig. 7). In our opinion the best explanation for these structures is thrusting/imbrication of the basement in a 3-4 km-deep basin during Devonian out-of-sequence thrusting. In 


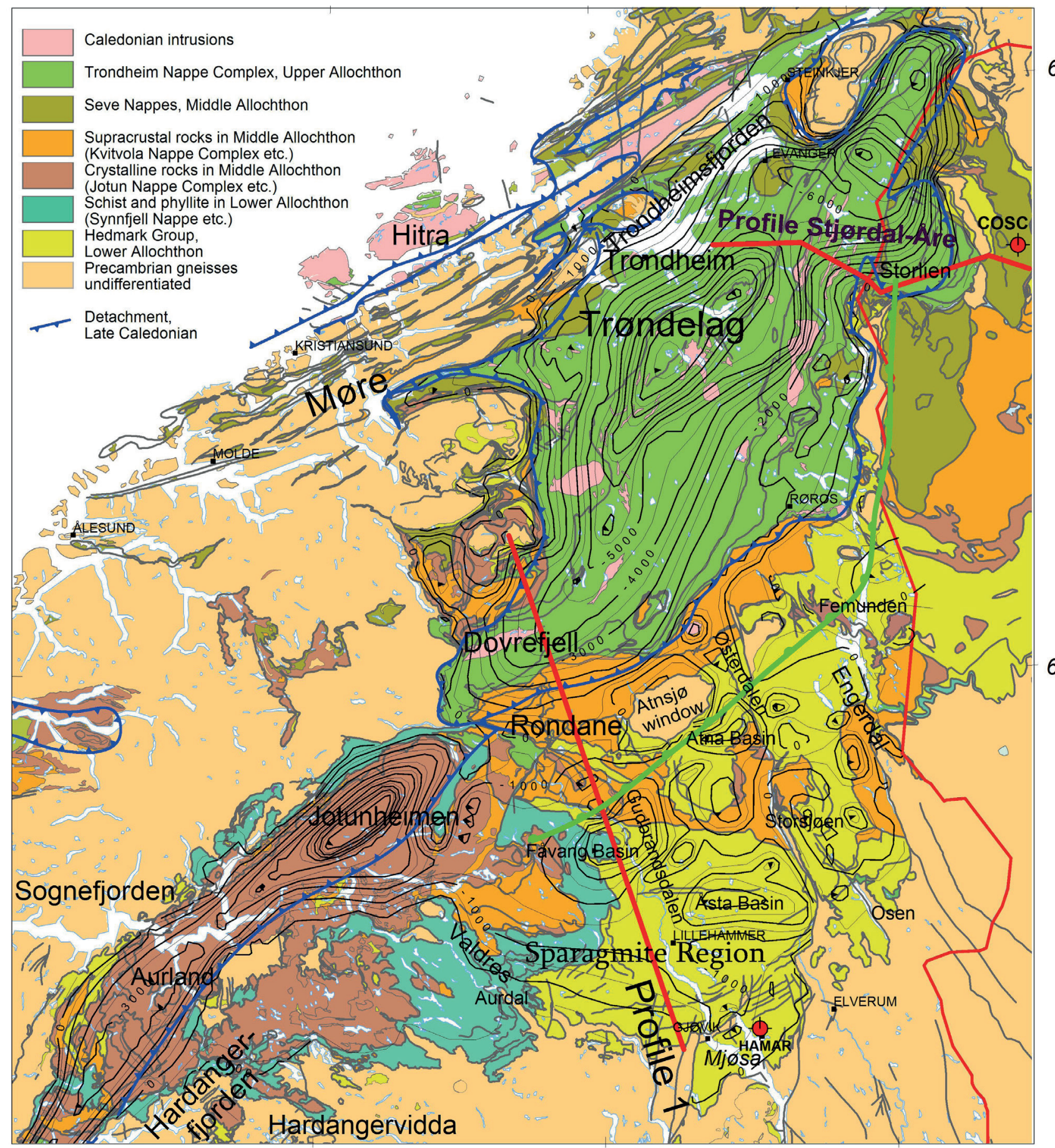

Figure 7. Simplified tectonic map of central and eastern Norway based on Koistinen et al. (2001). The estimated depth to Precambrian basement is shown with black contours. Caledonian detachments (Séranne, 1992; Osmundsen et al., 2006; Robinson et al., 2014) are shown as blue lines with the barbs towards the downthrown side. Profile 1 depicts the location of the interpretation profile shown in Figs. 8 \& 9. The green line indicates the interpreted boundary of Caledonian deformation of the Precambrian basement. The red circles depict the locations of the Hamar and COSC boreholes.

Finnmark, northern Norway (Fig. 1), several extensional structures in the marginal part of the Fennoscandian Shield have been described by Gayer et al. (1987) who showed how these early extensional structures had been reactivated during compression and thrusting of the Precambrian basement. A similar process with early extension and later compression has probably affected the northern part of Gudbrandsdalen.
Magnetotelluric anomalies (Cherevatova, et al., 2014) indicate a $10 \mathrm{~km}$-thick and 80 to $100 \mathrm{~km}$-long electrical conductor underneath the Middle Allochthon and Upper Allochthon in the vicinity of Profile 1 (Figs. 4-7) between Fåvang and Dovrefjell (Cherevatova, et al., 2014) and suggest that the lower part of this main anomaly may be related to the presence of Sveconorwegian rocks. The authors of the study suggested that the upper part, 
approximately $5 \mathrm{~km}$, is related to Cambro-Silurian metasedimentary rocks. However, it is difficult to separate Precambrian metasedimentary rocks from the younger metasedimentary rocks. We suggest that the deep conductor may represent graphite schists of the Brøttum Formation. The main anomaly terminates at the large Late Devonian normal fault in the Dovrefjell area. The magnetotelluric survey is therefore supporting the model of a depression located north of Hamar developing into a rift basin farther to the north-northwest.

\section{Collision with Laurentia}

Robinson et al. (2014) have divided the collision between Baltica and Laurentia into four stages, Stage 1 being the emplacement onto the Baltoscandian continental margin of a sequence of thrust sheets. In Trollheimen, many units of the Lower Allochthon are missing and the Åmotsdal Quartzite (equivalent to the Vangsås Formation?) is deposited directly on Precambrian basement, both on the Upper and the Lower basement, and there is no indication of the presence of thick rift-related sediments. The nappes of the Middle Allochthon are thrusted onto the Åmotsdal Quartzite. Stage 2 represents recumbent folding of both the basement and the nappes, Stage 3 is an out-of-sequence Devonian thrusting (Storli Thrust) and Stage 4 is represented by a low-angle detachment.

Hjerkinn

0

Middle Allochthon

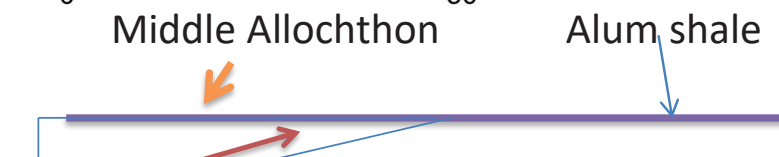

Middle Allochthon (Kvitvola Nappe Complex, including the Rondane and Valdres nappes)

The Middle Allochthon consists mainly of metamorphosed sediments from the western margin of the Fennoscandian Shield and Precambrian augen gneisses (Lamminen et al., 2011). On the Swedish side, highgrade metamorphic rocks with $442 \mathrm{Ma}$ old UHP rocks containing microdiamonds have been found within the Seve Nappe Complex in Åreskutan (Ladenberger et al., 2014). The exhumation and partial melting of the Seve rocks took place at around $430 \mathrm{Ma}$. The thrusting of the Seve Nappe Complex was probably associated with the formation of Silurian foreland basins, which later became deformed during the terminal stages of the Scandian orogeny. Ladenberger et al. (2014) suggested a long period of continent-continent collision due to the large depth of the UHP metamorphism and further suggested that the thrusting of the Seve Nappe took place at $420 \mathrm{Ma}$. The Precambrian basement windows can be followed from Storlien to the Atnsjø window. Within the area of 1:50,000 map-sheets Atnsjøen (Siedlecka, 1979) and Sollia (Siedlecka, 1981), the Middle Allochthon rests either directly on the basementor upon the Moelv Tillite (Siedlecka \& Ilebekk, 1982), the Vangsås Formation or in a few places on the Ringstrand and Alum Shale formations. Here, it is therefore difficult to define a sole thrust in the Alum Shale between the basement and the basal thrust plane of the Middle Allochthon. This is also confirmed by the lack of electrical conductors in the magnetotelluric survey in the Atnsjø Window (Smirnov et al., 2018). We interpret the structures in the basement and in the sedimentary cover under the Kvitvola Nappe Complex to be imbrications and minor thrusting related

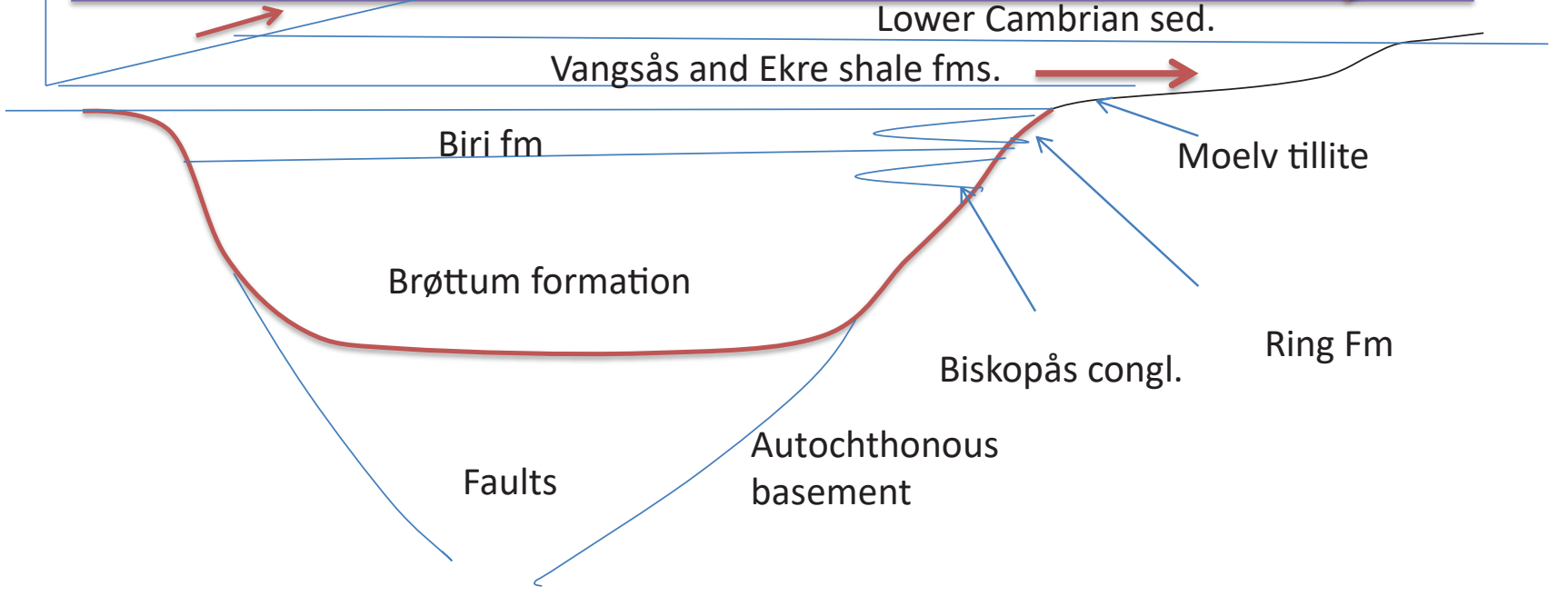

Figure 8. Geological section (Profile 1) through the Hedmark Basin during the thrusting of the Middle Allochthon at the end of the Silurian. 
to the transport of this nappe complex. This has parallels with the Åreskutan profile shown in Fig. 2.

There are still unanswered questions related to the early thrusting of the Middle Allochthon in the Rondane district and more data are needed, both geophysical surveys and radiometric dating. The deformation of the autochthonous/parautochthonous sedimentary succession between the Precambrian basement and the Middle Allochthon should be looked at closer. Stage 1 in the collisional history described in a cross-section by Robinson et al. (2014) explains the difference in the composition and in the structural development of the Precambrian rocks between the Lower and Middle allochthons (Fig. 8).

\section{Lower Allochthon}

Emplacement of the Lower Allochthon is interpreted to relate to out-of-sequence thrusting (Storli Thrust) of Early Devonian age that is clearly younger than the thrusting of the Middle Allochthon (Ladenberger et al., 2014; Robinson et al., 2014). In the ØstersundTrondheim profile, the thrust zone between the autochthonous and the allochthonous Precambrian basement corresponds to the Storli Thrust. In the Rondane district the thrust plane must be located below the deep rift basins because of the primary contact between basement and the Rendalen Formation.

Gee et al. (2010) distinguished between autochthonous basement and allochthonous basement. The basement window (Skardøra Antiform) close to the Norwegian border belongs to the allochthonous basement. The folding of both basement and the Middle Allochthon indicates that the thrusting of the allochthonous basement occurred after the thrusting of the Middle Allochthon (Stage 2, Robinson et al., 2014). The seismic interpretations by Gee et al. $(2010,2016)$ are differing substantially from previous gravity modelling in the central Trøndelag area. Rui \& Grønlie (1975), Åm et al. (1975), Wolff (1984), Skilbrei \& Sindre (1991), Skilbrei \& Kihle (1998), Skilbrei et al. (2002), Mekonnen (2004) and Ebbing et al. (2012) all interpreted a depth extent of the stacked Caledonian nappes in the order of 7-12 $\mathrm{km}$, whereas Gee et al. $(2010,2016)$ presented a depth of a few hundred metres below sea level of the Lower to Upper allochthons. We think that a significant part of the allochthonous basement interpreted by Gee et al. $(2010,2016)$ in the central Trøndelag area belongs to the Upper Allochthon as indicated in Figs. 4-7 in the present paper. Reflection seismic data can reveal thrust zones but not characterise the lithologies of the rocks between the individual thrusts.

The profile in Fig. 2 indicates a thrusting of more than $50 \mathrm{~km}$, exclusive of the shortening of the basement rocks (Stage 3, Robinson et al., 2014). The thrusting of the basement windows and shortening of the basement as shown in Fig. 9 occurred contemporaneously with the transport of the Hedmark Basin out of its original position into a large, complex inverted fold (i.e., the Ringsaker inversion, Skjeseth, 1963). The southwestern limit of the Hedmark Basin is probably located where there is a change in the magnetic pattern from a distinct NNW-SSE Precambrian basement lineation to a more Caledonian NE-SW lineation. This indicates a complex



Figure 9. Geological section (Profile 1) subsequent to the Devonian out-of-sequence thrusting. 
nappe structure below the basement window, which is also shown in the Østersund-Trondheim profile (Gee et al., 2010). This structural complexity is expressed by Precambrian basement slices in the Osen-Røa Nappe Complex in the northern part of Storsjøen and to the north of Storsjøen. Comparing the magnetic map with the geological map, there is a spatial relationship between the southeastern limit of Caledonian deformation of the Precambrian basement and the occurrence of basement slices in the above-lying nappe complex.

Southeast of the Caledonian deformation front in the Precambrian basement, the Osen-Røa Nappe Complex is thrusted above the Precambrian basement and a thin cover of autochthonous Cambrian sedimentary rocks (Fig. 9). The Osen-Røa Nappe Complex continues all the way to the Oslo Region (Bruton et al. 2010).

\section{Conclusions}

The topography of the Precambrian basement surface indicates a broad basin between Lillehammer and Rena which continues to the north-northwest following Sveconorwegian structures as shown on the aeromagnetic map. During the collision of Baltica with Laurentia, extensional faults were reactivated and the basin became subdivided into smaller structures with steep slopes on the northwestern parts of the depressions. Based on a magnetotelluric survey (Cherevatova et al., 2014), the basin can be followed below the Middle Allochthon to the north to Dovrefjell where it terminates at a late normal fault along the southern boundary of the Upper Allochthon.

The Middle Allochthon with the Kvitvola Nappe Complex was thrusted onto the Baltoscandian margin of the Fennoscandian Shield at around $420 \mathrm{Ma}$ and resulted in the formation of Silurian foreland basins. The Early Devonian Osen-Røa Nappe Complex was probably emplaced along the out-of-sequence Storli Thrust. The thrusting involved the sedimentary cover including deposits in the Hedmark Basin and the basement below the basin. The distance of transportation of the OsenRøa Nappe Complex may have been in the order of 100 $\mathrm{km}$.

Acknowledgements. AkerBP, BKK, ConocoPhillips, DEA, Eni, Equinor, Faroe Petroleum, Ineos, Lundin, Maersk, Neptune, NGU, NPD, Petrolia, Repsol, Spirit, Suncor, Total, VNG and Wintershall funded the Coop Project and the acquisition of the high-resolution fixed-wing aeromagnetic data. Arne Solli produced the bedrock map and Jomar Gellein made an updated aeromagnetic compilation. We also thank David Roberts for valuable comments and help in improving the text of the original manuscript.

\section{References}

Billström, K., Broman, C., Schneider, J., Pratt, W \& Skogsmo, G. 2012: $\mathrm{Zn}-\mathrm{Pb}$ Ores of Mississippi Valley Type in the Lycksele-Storuman district, northern Sweden: A possible rift-related Cambrian mineralisation event. Minerals 2012, 1, 169-207. https://doi.org/10.3390/min2030169.

Bingen, B. \& Viola, G. 2018: The early-Sveconorwegian orogeny in southern Norway: tectonic model involving delamination of the sub-continental lithospheric mantle. Precambrian Research 313, 170-204. https://doi.org/10.1016/j.precamres.2018.05.025.

Bjørlykke, A. 1979: Gjøvik og Dokka. Beskrivelse til de berggrunnsgeologiske kart 1816 I og 1816 IV (m 1:50 000) (med fargetrykt kart). NGU Skrifter 344, 1-48.

Bjørlykke, K. 1983: Subsidence and tectonics in Late Precambrian and Palaeozoic sedimentary basins of southern Norway. Norges geologiske undersøkelse Bulletin 380, 159-172.

Bjørlykke, K., Elvsborg, A \& Høy, T. 1976: Late Precambrian sedimentation in the central sparagmite basin of South Norway. Norwegian Journal of Geology 56, 233-290.

Braathen, A., Osmundsen, P.T., Nordgulen, Ø., Roberts, D. \& Meyer, G.B. 2002: Orogen-parallel extension of the Caledonides in northern Central Norway: an overview. Norwegian Journal of Geology 82, 225-241.

Briggs, I.C. 1974: Machine contouring using minimum curvature. Geophysics 39, 39-48. https://doi.org/10.1190/1.1440410.

Bruton, D.L., Gabrielsen, R.H. \& Larsen, B.T. 2010: The Caledonides of the Oslo Region, Norway - stratigraphy and structural elements. Norwegian Journal of Geology 90, 93-121.

Cherevatova, M., Smirnov, M., Korja, T., Kaikkonen, P., Pedersen, L.B., Hübert, J., Kamm, J. \& Kalscheuer, T. 2014: Crustal structure beneath southern Norway imaged by magnetotellurics. Tectonophysics 628 , 55-70. https://doi.org/10.1016/j.tecto.2014.04.036.

Dyrelius, D. 1980: Aeromagnetic interpretation in a geotraverse area across the central Scandinavian Caledonides. Geologiska Föreningens i Stockholm Förhandlingar 102, 421-438. https://doi.org/10.1080/11035898009454498.

Ebbing, J., England, R.W., Korja, T., Lauritsen, T., Olesen, O., Stratford, W. \& Weidle, C. 2012: Structure of the Scandes lithosphere from surface to depth. Tectonophysics 536, 1-24. https://doi.org/10.1016/j.tecto.2012.02.016.

Elvebakk, H. \& Lutro, O. 2008: Geofysisk logging av borehull ved Hamar Flyplass. NGU Report 2008.079, 17 pp.

Englund, J.O. 1973: Stratigraphy and structure of the Ringebu-Vinstra district, Gudbrandsdalen; with a short analysis of the western part of the Sparagmite Region in southern Norway. Norges geologiske undersøkelse 293, 1-58.

Eon, 2014: Fixed-wing Stavanger-Trondheim Aeromagnetic Survey 2013 (STAS-13). Final Survey Report, 36 pp.

Fossen, H., Pedersen, R.B., Bergh, S., \& Andresen, A. 2013: En fjellkjede blir til - Oppbygningen av Kaledonidene; ca. 500 - 405 millioner år. In Ramberg, I.B., Bryhni, I., Nøtvedt, A. \& Rangnes, K. (eds.): Landet blir til - Norges geologi. Norwegian Geological Society, pp. 182-233.

Gaal, G. \& Gorbatschev, R. 1987: An outline of the Precambrian evolution of the Baltic Shield. Precambrian Research 35, 15-52. https://doi.org/10.1016/0301-9268(87)90044-1.

Gabrielsen, R.H., Nystuen, J.P., Jarsve, E.M. \& Lundmark, A.M. 2015: The Sub-Cambrian Peneplain in southern Norway: its geological significance and its implications for post-Caledonian faulting, uplift and denudation. Journal of the Geological Society, London, 172, 777791.https://doi.org/10.1144/jgs2014-154.

Gabrielsen, R.H., Nystuen, J.P., Olesen, O. 2017: Fault distribution in the Precambrian basement of South Norway. Journal of Structural Geology 108, 269-289. https://doi.org/10.1016/j.jsg.2017.06.006.

Gayer, R.A., Rice, A.H.N., Roberts, D., Townsend C. \& Welbon A. 1987: Restoration of the Caledonian Baltoscandian margin from balanced cross-sections: the problem of excess continental crust. 
Transactions of The Royal Society of Edinburgh: Earth Sciences 78, 197-217. https://doi.org/10.1017/S026359330001110X.

Gee, D.G. 1975: A tectonic model for the central part of the Scandinavian Caledonides. American Journal of Science 275, 468515.

Gee, D.G., Juhlin, C., Pascal, C. \& Robinson, P. 2010: Collisional Orogeny in the Scandinavian Caledonides (COSC). Geologiska föreningens förhandlingar 132, 29-44.

Gee, D.G., Andrèasson P.G., Yuan L., Krill A. 2016: Baltoscandian margin, Sveconorwegian crust lost by subduction during Caledonian collisional orogeny. Geologiska föreningens förhandlingar 139, 36-51.

Geosoft, 2005: Montaj GridKnit, Grid extension for OASIS montaj 6.1. Tutorial and user guide, Geosoft Incorporated, $27 \mathrm{pp}$.

Hedin, P., Juhlin, C. \& Gee, D.G. 2012: Seismic imaging of the Scandinavian Caledonides to define ICDP drilling sites. Tectonophysics 554-557, 30-41. https://doi.org/10.1016/j.tecto.2012.05.026.

Hedin, P., Malehmir, A., Gee, D.G., Juhlin, C. \& Dyrelius, D. 2014: 3D interpretation by intergrating seismic and potential field data in the vicinity og the proposed COSC-1 drill site, central Swedish Caledonides. In Corfu, F., Gasser, D. \& Chew, D. M. (eds.): New Perspectives on the Caledonides of Scandinavia and Related Areas, Geological Society of London, Special Publications 390, pp. 301319.

Heiskanen, W.A. \& Moritz, H. 1967: Physical Geodesy. W.H. Freeman, San Francisco, 364 pp.

Henkel, H. \& Eriksson, L. 1987: Regional aeromagnetic and gravity studies in Scandinavia. Precambrian Research 35, 169-180. https://doi.org/10.1016/0301-9268(87)90052-0.

Hurich, C.A. 1996: Kinematic evolution of the lower plate during intracontinental subduction: An example from the Scandinavian Caledonides. Tectonics 15. https://doi.org/10.1029/96TC00828.

Hurich, C.A. \& Roberts, D. 1997: A seismic reflection profile from Stjørdalen to Outer Fosen, Central Norway: a note on the principal results. Norges geologiske undersøkelse Bulletin 433, 18-19.

Hurich, C.A., Palm, H., Dyrelius, D., Kristoffersen, Y., Wolff, F.C. \& Roberts, D. 1988: Activation of Precambrian basement in the Scandinavian Caledonides: views from seismic reflection data. Norges geologiske undersøkelse, Special Publication 3, 66-69.

Hurich, C.A., Palm, H., Dyrelius, D. \& Kristoffersen, Y. 1989: Deformation of the Baltic continental crust during Caledonide intracontinental subduction: views from seismic reflection data. Geology 17, 423-425. https://doi.org/10.1130/0091-7613(1989)017<0423:DOTBCC>2.3.CO;2.

Juhojuntti, N., Juhlin, C. \& Dyrelius, D. 2001: Crustal reflectivity underneath the Central Scandinavian Caledonides. Tectonophysics 334, 191-210. https://doi.org/10.1016/S0040-1951(00)00292-4.

Koistinen, T., Stephens, M.B., Bogatchev, V., Nordgulen, Ø., Wennerstrøm, M. \& Korhonen, J. 2001: Geological map of the Fennoscandian Shield, scale 1:2,000,000, Geological Surveys of Finland, Norway and Sweden and the Northwest Department of Natural Resources of Russia.

Korhonen, J.V., Aaro, S., All, T., Nevanlinna, H., Skilbrei, J.R., Säävuori, H., Vaher, R., Zhadanova, L., Koistinen, T., 2002a. Magnetic anomaly map of the Fennoscandian Shield 1: 2,000,000, Geological Surveys of Finland, Norway and Sweden and Ministry of Natural Resources of Russian Federation.

Korhonen, J.V., Aaro, S., All, T., Elo, S., Haller, L.Å., Kääriäinen, J., Kulinich, A., Skilbrei, J.R., Solheim, D., Säävuori, H., Vaher, R., Zhdanova, L., Koistinen, T. 2002b: Bouguer anomalymap of the Fennoscandian Shield 1:2,000,000, Geological Surveys of Finland, Norway and Sweden and Ministry of Natural Resources of Russian Federation.

Korja, T., Smirnov, M., Pedersen, L., Gharibi, M. 2008: Structure of the Central Scandinavian Caledonides and the underlying Precambrian basement, new constraints from magnetotellurics. Geophysical Journal International 175, 55-69.

https://doi.org/10.1111/j.1365-246X.2008.03913.x.

Ladenberger, A., Bèeri-Shlevin, Y., Claesson, S., Gee, D.G., Majka, J.
\& Romanova, I.V. 2014: Tectonometamorphic evolution of the Åreskutan Nappe - Caledonian history revealed by SIMS U-Pb zircon geochronology. In Corfu, F., Gasser, D. \& Chew, D.M. (eds.): New Perspectives on the Caledonides of Scandinavia and Related Areas, Geological Society of London, Special Publications 390, pp. 337-369. https://doi.org/10.1144/SP390.10.

Lamminen, J., Andersen, T. \& Nystuen, J.P. 2011: Zircon U-Pb ages and $\mathrm{Lu}-\mathrm{Hf}$ isotopes from basement rocks associated with Neoproterozoic sedimentary successions in the Sparagmite Region and adjacent aeas, South Norway: the crustal architecture of western Baltica. Norwegian Journal of Geology 91, 35-55.

Lamminen, J., Andersen, T. \& Nystuen, J.P. 2014: Provenance and rift basin architecture of the Neoproterozoic Hedmark Basin, South Norway inferred from $\mathrm{U}-\mathrm{Pb}$ ages and $\mathrm{Lu}-\mathrm{H}$ isotopes of conglomerate clasts and detrital zircons. Geological Magazine 152, 80-105. https://doi.org/10.1017/S0016756814000144.

Larson, S.A. \& Berglund, J. 1992: A chronological subdivision of the Transscandinavian Igneous Belt - three magmatic episodes? Geologiska Föreningens i Stockholm Förhandlingar 114, 459-460. https://doi.org/10.1080/11035899209453912.

Lutro, O. \& Tveten, E. 1996: Geologisk kart over Norge, berggrunnskart Årdal, Scale 1:250,000, Geological Survey of Norway.

Mekonnen, A.Y. 2004: A geophysical study of the Central Norwegian Caledonides. MSc. thesis, NTNU, Trondheim, 80 pp.

Midttømme, K., Ramstad, R.K., Elvebakk, H., Koziel, J., Lutro, O., Nordgulen, Ø., Olesen, O., Slagstad, T. \& Wissing, B. 2007: Thermal conductivity measurements. KONTIKI Final Report Continental Crust and Heat Generation In 3D. NGU Report 2007.042, 107 pp.

Morley, C.K. 1986: The Caledonian thrust front and palinspastic restorations in the southern Norwegian Caledonides. Journal of Structural Geology 8, 753-765.

https://doi.org/10.1016/0191-8141(86)90023-4.

Nasuti, A., Olesen, O., Baranwal, V. \& Dumais, M.A. 2015: Compilation of magnetic data. In Olesen, O., Barnawal, V., Brönner, M., Dalsegg, E., Dumais, M.A., Gellein, J., Gernigon, L., Heldal, T., Larsen, B.E., Lauritsen, T., Lutro, O., Maystrenko, Y., Nasuti, A., Roberts, D., Rueslåtten, H., Rønning, J.S., Slagstad, T., Solli, A. \& Stampolidis, A. 2015: Coop Phase 2 Crustal Onshore-Offshore Project. NGU Report 2015.063, 11-24 pp.

Nielsen A.T. \& Skovsbo N.H. 2010: The Lower Cambrian of Scandinavia : Depositional environment, sequence stratigraphy and paleogeography. Earth-Science Reviews 107, 207-310. https://doi.org/10.1016/j.earscirev.2010.12.004.

Nordgulen, Ø. 1999: Geologisk kart over Norge, berggrunnskart Hamar, scale 1:250,000, Geological Survey of Norway.

Novatem, 2012: Fixed-wing magnetic and radiometric survey of the Stad Region in Western Norway. C11089, Airborne survey for NGU Stad project, Norway 2012. Novatem internal report.

Novatem, 2014: Fixed-wing magnetic and radiometric survey of the Trøndelag Region in Norway. C12095, Airborne survey for NGU, TRAS-12 Norway 2011-2014 project. Novatem internal report.

Nystuen, J.P. 1975a: Nordre Osen, bedrock map 2017 IV, scale 1:50,000, Geological Survey of Norway.

Nystuen, J.P., 1975b: Jordet, bedrock map 2017 I, scale 1:50,000, Geological Survey of Norway.

Nystuen, J.P., 1976a: Engeren, bedrock map 2018 II, scale 1:50,000, Geological Survey of Norway.

Nystuen, J.P., 1976b: Engerdal, bedrock map 2018 I, scale 1:50,000, Geological Survey of Norway.

Nystuen, J.P. 1976c: Facies and sedimentation of the Late Precambrian Moelv Tillite in the eastern part of the Sparagmite Region, Southern Norway. Norges geologiske undersøkelse Publications 329, 1-70.

Nystuen, J.P. 1981: The late Precambrian 'sparagmites' of southern Norway: a major Caledonian allochthon - the Osen Røa Nappe Complex. American Journal of Science 281, 69-94.

https://doi.org/10.2475/ajs.281.1.69.

Nystuen, J.P. 1983: Nappe and thrust structures in the Sparagmite 
Region, southern Norway. Norges geologiske undersøkelse Bulletin $380,67-83$.

Nystuen, J.P. 2008: Break-up of the Precambrian continent, Late Precambrian, from Precambrian to Palaeozoic; 850-541 million years. In Ramberg, I.B., Bryhni, I., Nøtvedt, A. \& Rangnes, K. (eds.): The making of a land - Geology of Norway, Norwegian Geological Society, pp. 120-147.

Nystuen, J.P., Andresen, A., Kumpulainen, R. \& Siedlecka, A. 2008: Neoproterozoic basin evolution in Fennoscanda, East Greenland and Svalbard. Episodes 31, 35-43.

Olesen, O., Balling, N., Barrère, C., Breiner, N., Davidsen, B., Ebbing, J., Elvebakk, H., Gernigon, L., Koziel, J., Midttømme, K., Nordgulen, Ø., Olsen, L., Pascal, C., Ramstad, R.K., Osmundsen, P.T., Rønning, J.R., Skilbrei, J.S., Slagstad, T. \& Wissing, B. 2007a: KONTIKI Final Report, Continental Crust and Heat Generation In 3D. NGU Report 2007.042, $438 \mathrm{pp}$.

Olesen, O., Ebbing, J. \& Skilbrei, J.S. 2007b: Depth to crystalline basement on the Norwegian continental shelf. KONTIKI Final Report Continental Crust and Heat Generation In 3D. NGU Report 2007.042, pp. 157-180

Olesen, O., Brönner, M., Ebbing, J., Gellein, L., Gernigon, L., Koziel, J., Lauritsen, S., Myklebust, R., Pascal, C., Sand, M, Solheim, D. \& Urov, S. 2010: New aeromagnetic and gravity compilations from Norway and adjacent areas: methods and applications. In Vining, V.A. \& Pickering, S.C. (eds.): Petroleum geology: From mature basins to new fronters - Proceedings from the $7^{\text {th }}$ Petroleum Geology Conference, Geological Society of London, pp. 559-586.

Olesen, O., Barnawal, V., Brönner, M., Dalsegg, E., Dumais, M.A., Gellein, J., Gernigon, L., Heldal, T., Larsen, B.E., Lauritsen, T., Lutro, O., Maystrenko, Y., Nasuti, A., Roberts, D., Rueslåtten, H., Rønning, J.S., Slagstad, T., Solli, A. \& Stampolidis, A. 2015: Coop Phase 2 Crustal Onshore-Offshore Project. NGU Report 2015.063.

Osmundsen, P.T., Eide, E.A., Haabesland, N.E., Roberts, D., Andersen, T.B., Kendrick, M., Bingen, B., Braathen, A. \& Redfield, T.F. 2006: Kinematics of the Høybakken detachment zone and the MøreTrøndelag Fault Complex, central Norway. Journal of the Geological Society of London 163,303-318. https://doi.org/10.1144/0016-764904-129.

Palm, H., Gee, D.G., Dyrelius, D. \& Björklund, L. 1991: A reflection seismic image of Caledonian structure in Central Sweden, Geological Survey of Sweden Series 75, 1-36.

Rice, A.H.N. \& Anderson, M.W. 2016: Restoration of the external Scandinavian Caledonides. Geological Magazine 153, 1136-1165. https://doi.org/10.1017/S0016756816000340.

Roberts, D. \& Stephens, M.B. 2000: Caledonian orogenic belt. In Lundquist, T. \& Autio, S. (eds.): Description to the bedrock map of Fennoscandia, Geological Survey of Finland Special paper 28, pp. $79-104$.

Robinson, P., Roberts, D., Gee, D.G. \& Solli, A. 2014: A major synmetamorphic Early Devonian thrust and extensional fault system in the Mid Norway Caledonides: relevance to exhumation of HP and UHP extensional fault system in the Mid Norway. In Corfu, F., Gasser, D. \& Chew, D.M. (eds): New Perspectives on the Caledonides of Scandinavia and Related Areas, Geological Society of London, Special Publications 390, 1-8.

Rodionov, A., Ofstad, F., Stampolidis, A. \& Tassis, G. 2015: Helicopterborne magnetic, electromagnetic and radiometric geophysical survey in Gauldal and Sokndal area, Sør Trøndelag County. NGU Report 2015.053, $31 \mathrm{pp}$

Rui, L.J. \& Grønlie, G. 1975: A comment on a gravity interpretation of the Horg area in the Trondheim Region, Norwegian Caledonides. Norwegian Journal of Geology 55, 303-308.

Séranne, M. 1992: Late Palaeozoic kinematics of the Møre-Trøndelag Fault Zone and adjacent areas, central Norway. Norwegian Journal of Geology 72, 141-158.

Siedlecka, A. 1979: Atnsjøen, bedrock map 1818 IV, scale 1:50,000, Geological Survey of Norway.
Siedlecka, A., 1981. Sollia, bedrock map 1818 I, scale 1:50,000, Geological Survey of Norway.

Siedlecka, A., \& Ilebekk, S. 1982. Forekomster av tillitt på nordsiden av Atnsjøen-vinduet, Syd-Norge. Norges geologiske undersøkelse Bulletin 373, 33-37.

Siedlecka, A., Nystuen, J.P., Englund, J.O. \& Hossack, J. 1987: Lillehammer, bedrock map, scale 1:250,000, Geological Survey of Norway.

Sigmond, E.M.O. 1998: Odda, bedrock map, scale 1:250,000, Geological Survey of Norway.

Simpson, R.W., Jachens, R.C. \& Blakely, R.J. 1983: AIRYROOT: A Fortran program for calculating the gravitational attraction of an Airy isostatic root out to $166.7 \mathrm{~km}$. United States Department of the Interior, Geological Survey Open-File Report, 83-883, 24 pp.

Skilbrei, J.R., 1990: Structure of the Jotun Nappe Complex, Southern Norwegian Caledonides: Ambiquity of Gravity Modelling and Reinterpretation. NGU Report 89.169, 26 pp.

Skilbrei, J.R. \& Kihle, O. 1998: Gravity modelling and petrophysical data from western Norway. NGU Report 98.008, $36 \mathrm{pp}$.

Skilbrei, J.R. \& Sindre, A. 1991: Tolkning av gravimetri langs ILPprofilet, Hemne-Storlien. NGU Report 91.171,27 pp.

Skilbrei, J.R., Kihle, O., Olesen, O., Gellein, J., Sindre, A., Solheim, D. \& Nyland, B. 2000: Gravity anomaly map, Norway and adjacent ocean areas. Scale 1:3,000,000, Geological Survey of Norway.

Skilbrei, J.R., Olesen, O., Osmundsen, P.T., Kihle, O., Aaro, S. \& Fjellanger, E. 2002: A study of basement structures and onshoreoffshore correlations in Central Norway. Norwegian Journal of Geology 82, 263-279.

Skjeseth, S. 1963: Contribution to the geology of the Mjøsa districts and the classical sparagmite area in southern Norway. Norges geologiske undersøkelse Bulletin 220, 1-126.

Smirnov, M.Y., Gradman, S., Olesen, O. \& Bjørlykke, A. 2018: Magnetotelluric measurements in the Atna area, Southern Norway. Geophysical Research Abstracts 20, EGU2018-8422, European Geoscience General Assembly, 9-13 April, Vienna, Austria, p. 1.

Strand, T. 1954: Aurdal, beskrivelse til det geologiske gradteigskart, scale 1:100,000. Geological Survey of Noway Bulletin 185, 1-71.

Sæther, T. 1979: Storsjøen, bedrock map 1918 II, scale 1:50,000, Geological Survey of Norway.

Sæther, T. \& Nystuen, J.P. 1981: Tectonic framework, stratigraphy, sedimentation andvolcanism of the Late Precambrian Hedmark Group, Østerdalen, south Norway. Norwegian Journal of Geology 61, 193-211.

Törnebohm, A.E. 1888: Om fjällproblemet. Geologiska Föreningens $i$ Stockholm Förhandlingar 10,328-336. https://doi.org/10.1080/11035898809444211.

Törnebohm A.E. 1896: Grunddragen af det centrala Skandinaviens bergbygnad. Kongliga Svenska Vetenskaps-Akademiens Handlingar $28,1-210$.

Wolff, F.C. 1984: Regional geophysics of the Central Norwegian Caledonides. Norges geologiske undersøkelse Bulletin 397, 1-27.

Worsley, D., Baarli B.G., Howe, M.P.A., Hjaltason, F. \& Alm, D. 2011: New data on the Bruflat Formation and the Llandovery/Wenlock transition in the Oslo Region, Norway. Norwegian Journal of Geology 91, 101-120.

Åm, K., Oftedahl, C. \& Sindre, A. 1975: Interpretation of gravity data from the Horg Syncline of the Trondheim Region Caledonides. Norges geologiske undersøkelse Bulletin 287, 27-39. 